\title{
4-(Succinimido)-1-butane sulfonic acid as a Brönsted acid catalyst for the synthesis of pyrano[4,3-b]pyran derivatives using thermal and ultrasonic irradiation
}

\author{
Nader Ghaffari Khaligh *, Sharifah Bee Abd Hamid \\ Nanotechnology \& Catalysis Research Centre, NANOCAT, University Malaya, Kuala Lumpur, Malaysia
}

\section{A R T I C L E I N F O}

\section{Article history:}

Received 7 January 2015

Accepted 29 January 2015

Published 20 May 2015

\section{Keywords:}

Brönsted acid

Pyrano[4,3-b]pyran

4-Hydroxy-6-methylpyran-2-one

Three-component reaction

One-pot condensation

\begin{abstract}
A B S T R A C T
4-(Succinimido)-1-butane sulfonic acid was shown to be an efficient and reusable Brönsted acid catalyst for the synthesis of pyrano[4,3-b]pyran derivatives using thermal and ultrasonic conditions. The catalyst was prepared by mixing succinimide and 1,4-butanesultone, which is simpler and safer than the preparation of succinimide sulfonic acid. This method has the advantages of high yield, clean reaction, simple methodology, and short reaction time. The catalyst can be recycled without loss of activity.
\end{abstract}

(C) 2015, Dalian Institute of Chemical Physics, Chinese Academy of Sciences. Published by Elsevier B.V. All rights reserved.

\section{Introduction}

Pyridone and pyran structural units occur widely in various molecules exhibiting a wide range of biological activities and serve as a specific nonnucleoside reverse transcriptase inhibitor of HIV-1 [1,2], inotropic and vasodilatatory drugs [3], antitumors and antioxidants [4,5], rhinovirus 3C protease inhibitors [6], anticancers [5,7-9], potential antiviral and antileishmanial agents [10]. Compounds containing a 2-pyridone moiety fused with a substituted pyran ring are reported as a $\mathrm{Ca}^{2+}$ inhibitor [11], which is active against multidrug resistant KB-VI cancer cells and has a selective cytotoxicity profile [12]. Therefore, a variety of synthetic strategies have been developed for the preparation of dihydropyrano[4,3- $b]$ pyran derivatives through the formation of the intermediate Knoevenagel products and their subsequent reactions with 4-hydroxy-6methylpyran-2-one [13] or a multicomponent reaction of pyrone with malononitrile and various aromatic aldehydes [11].
Homogeneous inorganic acids and alkalis such as $\mathrm{H}_{2} \mathrm{SO}_{4}$, $\mathrm{KOH}$, and $\mathrm{NaOH}$ are catalysts in organic transformations. However, these catalysts have disadvantages: they are strongly corrosive and nonrenewable and easily cause environmental pollution through wastewater or sludge discharging. Solid acids as economical and ecologically benign catalysts offer unique properties and important advantages over the homogeneous inorganic acids in organic synthesis, for example, operational simplicity, environmental compatibility, nontoxicity, low cost, and ease of isolation [12-17]. However, they have some disadvantages. For example, although zeolites demonstrate high activity, their reactions typically give a variety of undesired byproducts due to the higher temperature employed and metal triflates are costly and moisture sensitive. Also, some catalysts require a special effort to prepare $[18,19]$. Ion exchange resins are limited in application because they are thermally unstable above $120^{\circ} \mathrm{C}$ in the acid form [20].

Green chemistry with its twelve principles was proposed to

* Corresponding author. Tel: +98-2166431738; Fax: +98-2166934046; E-mail: ngkhaligh@guilan.ac.ir DOI: 10.1016/S1872-2067(14)60307-7 | http://www.sciencedirect.com/science/journal/18722067 | Chin. J. Catal., Vol. 36, No. 5, May 2015 
increase the efficiency of synthetic methods, to use less hazardous solvents, reduce the stages of the synthetic routes and minimize waste as far as practically possible [21]. One of the key areas of green chemistry is the replacement of the traditional thermal methods with eco-environmental technology such as the use of ultrasound. The use of ultrasound gives enhanced reaction rates, formation of purer products, improved yields, suppression of side products, increased selectivities, easier experimental procedures, and use of milder conditions [22-24]. A survey of the literature reveals that a number of researchers have demonstrated the efficacy of sonication under solvent-free conditions, but at least one of the phases of the reaction mixture was a liquid [25,26]. In addition, the use of a heterogeneous catalyst in a dry medium can improve the production process, eliminating or transforming unwanted and/or toxic byproducts and avoiding the need for tedious separation.

Recently, succinimide sulfonic acid was synthesized and their application in the variety of organic transformations was investigated [27-30]. Here, a new Brönsted acid, namely, 4-(succinimido)-1-butane sulfonic acid (SBSA) is introduced and its application in the promotion of the synthesis of dihydropyrano[4,3-b]pyran derivatives is described. The present study developed a new preparative procedure for this class of heterocyclic scaffolds by utilizing SBSA under solvent-free conditions.

\section{Experimental}

\subsection{General}

Chemicals were purchased from Fluka AG, Merck, and Synthetic Chemicals Ltd. Reaction monitoring and purity determination of the products were accomplished by TLC or GC-MS on an Agilent GC-Mass-6890 instrument under $70 \mathrm{eV}$ conditions. Fouriter transform infrared (FTIR) spectra were obtained using a Perkin-Elmer spectrometer 781 and Bruker Equinox 55 using $\mathrm{KBr}$ pellets for solid samples and neat liquid samples in the range of $4000-400 \mathrm{~cm}^{-1}$. In all the cases, the ${ }^{1} \mathrm{H}$ NMR spectra were recorded with a Bruker Avance $400 \mathrm{MHz}$ instrument. Mass spectra (MS) and high resolution mass spectrometry (HRMS) were recorded with PESciex Model API 3000 and Waters-Micromass Q-ToF Micro instruments, respectively. Microanalysis was performed on a Perkin-Elmer 240-B microanalyzer. Melting points (M.p.) were recorded on a Büchi B-545 apparatus using open capillary tubes. Sonication was performed in a Bandelin Sonorex reactor with a frequency of $35 \mathrm{kHz}$ and a nominal power of $200 \mathrm{~W}$, and built-in heating to $30-80{ }^{\circ} \mathrm{C}$ which was thermostatically adjustable. The reaction vessel was placed inside the ultrasonic bath containing water.

\subsection{Synthesis of SBSA}

Succinimide (0.99 g, $10 \mathrm{mmol})$ was added to 1,4-butane sultone (1.5 mL, $14.4 \mathrm{mmol})$ and stirred continuously for $10 \mathrm{~h}$ at $40-50{ }^{\circ} \mathrm{C}$ using solar energy to obtain SBSA as a white solid. The viscous liquid was washed with diethyl ether three times to remove unreacted starting materials, and a white solid was obtained. The resulting SBSA was dried to constant weight in vacuum at $60{ }^{\circ} \mathrm{C}$. White needles were obtained by crystallization in a mixture of ethanol and water using a slow evaporation technique (2.12 g, yield 90.2\%). M.p. $222{ }^{\circ} \mathrm{C}$ (dec.); IR (KBr): $v_{\max } 3140,3090,2980,2940,1740,1640,1600,1460,1380$, 1190, 1120, $1040 \mathrm{~cm}^{-1}$; ${ }^{1} \mathrm{H}$ NMR (300 MHz, $\left.{ }_{2} \mathrm{O}\right): \delta 1.75-1.68$ (m, 2H, - $\mathrm{CH}_{2}-$ ) $2.03-1.91\left(\mathrm{~m}, 2 \mathrm{H},-\mathrm{CH}_{2}-\right), 2.64$ (s, 4H, $-\mathrm{CH}_{2}-\mathrm{CH}_{2}-$, succinimide), $2.95\left(\mathrm{t}, J=7.4 \mathrm{~Hz}, 2 \mathrm{H},-\mathrm{CH}_{2}-\mathrm{S}\right.$ ), 4.23 $\left(\mathrm{t}, J=6.9 \mathrm{~Hz}, 2 \mathrm{H},-\mathrm{CH}_{2}-\mathrm{N}\right) \mathrm{ppm}$; ${ }^{13} \mathrm{C}$ NMR $\left(75 \mathrm{MHz}, \mathrm{D}_{2} \mathrm{O}\right): \delta 22.3$ ( $\mathrm{C}_{2}$ of butane), 28.2 ( $\mathrm{C}_{3}$ of butane), $29.3\left(\mathrm{CH}_{2}\right.$ of succinimide), $49.3\left(\mathrm{~N}-\mathrm{CH}_{2}\right), 51.2\left(\mathrm{~S}-\mathrm{CH}_{2}\right), 186.5$ (C=0) ppm; HRMS (ENI): $m / z$ calcd. for $\mathrm{C}_{8} \mathrm{H}_{12} \mathrm{NO}_{5} \mathrm{~S}$ [M-1] $]^{+}: 234.0436$; Found: 234.0431 .

\subsection{Preparation of 2-amino-4-aryl-7-methyl-5-oxo-4,5- dihydropyrano[4,3-b]pyran-3-carbonitriles (2)}

In a $25-\mathrm{mL}$ round bottom flask, a mixture of 4-hydroxy-6methylpyran-2-one (1.0 mmol), aromatic aldehyde (1.0 mmol), and malononitrile $(1.0 \mathrm{mmol})$ were mixed in the presence of 4-(succinimido)-1-butane sulfonic acid $\left(10 \mathrm{mg}\right.$ ) at $60{ }^{\circ} \mathrm{C}$ under solvent-free condition and ultrasound irradiation for an appropriate time. After completion of the reaction (monitored by TLC), the reaction mixture was cooled to room temperature and water was added, and the solid precipitated was filtered to separate the catalyst. Water was evaporated under reduced pressure and the catalyst was recovered and used for the next run. The solid product was recrystallized from ethanol to yield the pure product.

2c: 2-amino-4-(4-fluorophenyl)-7-methyl-5-oxo-4,5-dihydropyrano[4,3-b]pyran-3-carbonitrile. Colorless solid; M.p. = 221-223 ${ }^{\circ} \mathrm{C}$; IR (KBr) $v_{\max }=3369,3317,3195,2924,2194$, $1715,1678,1641,1618,1591,1378,1259,1138,1091,1032$, $978 \mathrm{~cm}^{-1}$; ${ }^{1} \mathrm{H}$ NMR (400 MHz, DMSO-d6): $\delta=2.19\left(\mathrm{~s}, 3 \mathrm{H}, \mathrm{CH}_{3}\right.$ ), 4.28 (s, 1H, CH), 6.31 (s, 1H, CH), 7.19 (brs, 2H, NH 2 ), 7.19-7.22 (m, 2H, ArH), 7.31-7.34 (m, 2H, ArH) ppm.

2d: 2-amino-4-(4-bromophenyl)-7-methyl-5-oxo-4,5-dihydropyrano[4,3-b]pyran-3-carbonitrile. Colorless solid; M.p. = 225-227 ${ }^{\circ} \mathrm{C}$; IR (KBr) $v_{\max }=3381,3322,3197,2921,2204$, 1712, 1676, 1643, 1611, 1596, 1384, 1263, 1141, 1095, 1036, $972 \mathrm{~cm}^{-1}$; ${ }^{1} \mathrm{H}$ NMR (400 MHz, DMSO- $\left.d_{6}\right): \delta=2.21\left(\mathrm{~s}, 3 \mathrm{H}, \mathrm{CH}_{3}\right.$ ), 4.31 (s, 1H, CH), 6.27 (s, 1H, CH), 7.18 (d, 2H, J = 8.0 Hz, ArH), $7.25\left(\mathrm{~s}, 2 \mathrm{H}, \mathrm{NH}_{2}\right), 7.46(\mathrm{~d}, 2 \mathrm{H}, J=8.0 \mathrm{~Hz}, \mathrm{ArH}) \mathrm{ppm}$.

2m: 4,4'-(1,4-phenylene)bis(2-amino-7-methyl-5-oxo-4,5dihydropyrano[4,3-b]pyran-3-carbonitrile). Colorless solid; M.p. $=256-258{ }^{\circ} \mathrm{C}$; IR (KBr): $v_{\max }=3372,3317,3196,2196$, 1699, 1673, 1614, 1463, $1383 \mathrm{~cm}^{-1}$; ${ }^{1} \mathrm{H}$ NMR (400 MHz, DMSO- $\left.d_{6}\right): \delta=2.16\left(\mathrm{~s}, 6 \mathrm{H}, 2 \mathrm{CH}_{3}\right), 4.19(\mathrm{~s}, 2 \mathrm{H}, 2 \mathrm{CH}), 6.22(\mathrm{~s}, 2 \mathrm{H}$, 2CH), 7.06 (s, 4H, Ar-H), 7.13 (brs, 4H, 2NH 2 ppm; ${ }^{13} \mathrm{C}$ NMR (100 MHz, DMSO- $\left.d_{6}\right): \delta=18.9,35.5,57.8,98.0,119.4,127.5$, 130.1, 136.6, 142.4, 158.6, 161.2, 161.9, 162.8, 174.8 ppm; MS(ESI): $m / z[\mathrm{M}+1]^{+}=483$; Anal. Calcd. for $\mathrm{C}_{26} \mathrm{H}_{18} \mathrm{~N}_{4} \mathrm{O}_{6}: \mathrm{C}$, 64.73\%; H, 3.73\%; N, 11.62\%. Found: C, 64.62\%; H, 3.83\%; N, $11.78 \%$.

\section{Results and discussion}

An aim of our research is to introduce an eco-efficient 
methodology that allows decreasing the amount of waste and less use of hazardous materials. In the traditional preparation of succinimide- $N$-sulfonic acid, chlorosulfonic acid is stirred with succinimide to generate gaseous $\mathrm{HCl}$ [27-30]. This has the disadvantage of using chlorosulfonic acid which causes severe burns and reacts exothermically and violently with water producing $\mathrm{H}_{2} \mathrm{SO}_{4}, \mathrm{HCl}$, and large quantities of dense white acid fumes. It is very toxic on inhalation and corrosive to metals. The present catalyst prepared by mixing succinimide and 1,4-butane sultone is simpler and safer. The synthesis of 4-(succinimido)-1-sulfonic acid involved stirring the same equivalents of succinimide and 1,4-butane sultone at $40-50{ }^{\circ} \mathrm{C}$ for $6 \mathrm{~h}$. The present method does not use a traditional heater. Instead, 10 mirrors reflected sunlight onto the $25 \mathrm{~mL}$ round bottom flask. When the concentrated sunlight strikes the round bottom flask, it heats the reaction mixture to $40-60{ }^{\circ} \mathrm{C}$ (Scheme 1). The viscous liquid was washed with diethyl ether, and a white solid was obtained. The resulting SBSA was dried to constant weight in vacuum. The structure was confirmed by IR, ${ }^{1} \mathrm{H}$ NMR, and ${ }^{13} \mathrm{C}$ NMR. The content of water of the SBSA was 5.4\% from a Karl-Fischer titration method. SBSA is soluble in DMSO, DMF, water, methanol, and ethanol. It is immiscible with diethyl ether, ethyl acetate, and $\mathrm{CH}_{2} \mathrm{Cl}_{2}$. So the catalyst can be separated conveniently from the products by a simple phase separation.

To evaluate the effect of the amount of SBSA, the condensation of 4-hydroxy-6-methylpyran-2-one, 4-nitrobenzaldehyde (1e), and malononitrile was carried out in the presence of different amounts of catalyst (2.1, 4.2, and $8.5 \mathrm{~mol} \%)$ under solvent-free conditions (Scheme 2). It was observed that $4.2 \mathrm{~mol} \%$ of SBSA was an optimum amount for this model reaction to furnish the desired product in high yield. Increasing the amount of the catalyst beyond $4.2 \mathrm{~mol} \%$ did not increase the yield noticeably. The different reaction temperatures (r.t.-80 ${ }^{\circ} \mathrm{C}$ ) were compared and the results showed that $88 \%$ of 2-amino-4-(4-nitrophenyl)-7-methyl-5-oxo-4,5-dihydropyrano

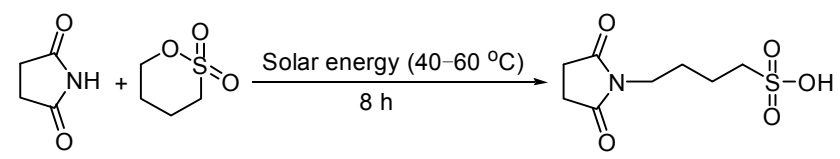

Scheme 1. Synthesis of 4-(succinimido)-1-butane sulfonic acid (SBSA) using solar energy.

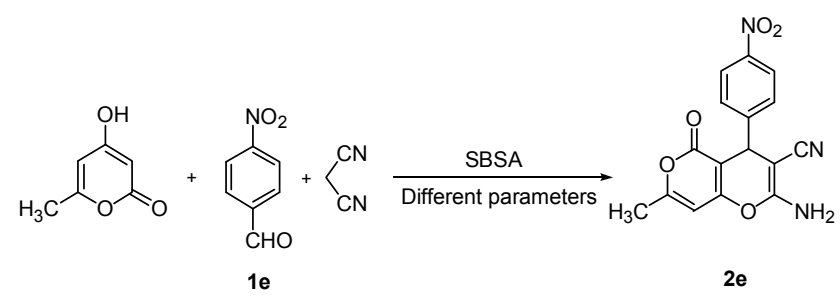

Scheme 2. Synthesis of 2-amino-4-(4-nitrophenyl)-7-methyl-5-oxo-4,5dihydropyrano $[4,3-b]$ pyran-3-carbonitrile derivatives in the presence of SBSA under various reaction conditions.

[4,3- $b]$ pyran-3-carbonitrile was obtained in the presence of 4.2 mol\% SBSA at $60{ }^{\circ} \mathrm{C}$ in $60 \mathrm{~min}$. Higher temperatures caused more spots on the TLC and it was deduced that byproducts were obtained. The reaction was not complete at $60{ }^{\circ} \mathrm{C}$ even after $4 \mathrm{~h}$ in the absence of SBSA, and only 38\% of $\mathbf{2 e}$ was obtained. The model reaction was also carried out under the optimized conditions in the presence of succinimide- $N$-sulfonic acid (SuSA), but only $54 \%$ of $2 \mathbf{e}$ was obtained. It was deduced that this reaction was catalyzed by SBSA more than by succinimide- $N$-sulfonic acid.

To study the effect of ultrasonic irradiation, the model reaction was performed using SBSA at room temperature under ultrasonic irradiation. In general, ultrasound has chemical and mechanical effects. The main advantages of the uses of ultrasound in the processing of liquids are directly related to the physical effects of acoustic cavitation [31]. Because this work used a heterogeneous catalytic system in a dry medium, the main effect of ultrasound was due to its mechanical effect. The mechanical effects of ultrasound lead to a reduction of particle

Table 1

Synthesis of 2-amino-4-aryl-7-methyl-5-oxo-4,5-dihydropyrano[4,3-b]pyran-3-carbonitriles in the presence of SBSA a .

\begin{tabular}{|c|c|c|c|c|c|c|c|c|c|}
\hline \multirow{2}{*}{ Entry } & \multirow{2}{*}{ Substrate (1) } & \multirow{2}{*}{ Product (2) } & \multicolumn{2}{|c|}{ Thermal condition $\left(60^{\circ} \mathrm{C}\right)$} & \multicolumn{2}{|c|}{ Ultrasound irradiation } & \multicolumn{2}{|c|}{ M.p. $\left({ }^{\circ} \mathrm{C}\right)$} & \multirow{2}{*}{ Ref. } \\
\hline & & & Time (min) & Yield b $(\%)$ & Time (min) & Yield ${ }^{\mathrm{b}}(\%)$ & Found & Reported & \\
\hline 1 & $\mathrm{C}_{6} \mathrm{H}_{5}-\mathrm{CHO}$ & $\mathbf{a}$ & 80 & 80 & 15 & 92 & 236 & $236-238$ & {$[35]$} \\
\hline 2 & $4-\mathrm{Cl}-\mathrm{C}_{6} \mathrm{H}_{4}-\mathrm{CHO}$ & b & 75 & 84 & 12 & 90 & $228-230$ & $231-232$ & [39] \\
\hline 3 & $4-\mathrm{F}-\mathrm{C}_{6} \mathrm{H}_{4}-\mathrm{CHO}$ & c & 70 & 82 & 12 & 92 & $221-223$ & $223-225$ & [10] \\
\hline 4 & $4-\mathrm{Br}-\mathrm{C}_{6} \mathrm{H}_{4}-\mathrm{CHO}$ & d & 80 & 84 & 14 & 90 & $225-227$ & $218-220$ & [10] \\
\hline 5 & $4-\mathrm{NO}_{2}-\mathrm{C}_{6} \mathrm{H}_{4}-\mathrm{CHO}$ & e & 60 & 88 & 10 & 95 & $220-222$ & $216-218$ & [37] \\
\hline 6 & $4-\mathrm{CH}_{3}-\mathrm{C}_{6} \mathrm{H}_{4}-\mathrm{CHO}$ & f & 90 & 72 & 15 & 90 & $218-220$ & $223-225$ & [38] \\
\hline 7 & $4-\mathrm{CH}_{3} \mathrm{O}-\mathrm{C}_{6} \mathrm{H}_{4}-\mathrm{CHO}$ & g & 95 & 70 & 15 & 88 & $210-212$ & $205-207$ & [35] \\
\hline 8 & $3-\mathrm{Br}-\mathrm{C}_{6} \mathrm{H}_{4}-\mathrm{CHO}$ & $\mathbf{h}$ & 70 & 69 & 15 & 90 & $217-219$ & 216 & [36] \\
\hline 9 & $3-\mathrm{NO}_{2}-\mathrm{C}_{6} \mathrm{H}_{4}-\mathrm{CHO}$ & $\mathbf{i}$ & 62 & 74 & 12 & 93 & $218-220$ & $234-236$ & [37] \\
\hline 10 & $3,4-\left(\mathrm{CH}_{3} \mathrm{O}\right)_{2}-\mathrm{C}_{6} \mathrm{H}_{3}-\mathrm{CHO}$ & $\mathbf{j}$ & 95 & 70 & 18 & 90 & $198-202$ & $198-202$ & [36] \\
\hline 11 & Furfural & $\mathbf{k}$ & 80 & 78 & 15 & 92 & $118-120$ & $223-224$ & {$[5]$} \\
\hline 12 & 2-Thiophene carbaldehyde & 1 & 80 & 74 & 15 & 90 & $238-240$ & $242-244$ & [5] \\
\hline 13 & $1,4-(\mathrm{CHO})_{2}-\mathrm{C}_{6} \mathrm{H}_{4}$ & $\mathbf{m}$ & 90 & 80 & 20 & 94 & $256-258$ & - & - \\
\hline 14 & 4-Dimethylaminobenzaldehyde & $\mathbf{n}$ & 120 & - & 120 & - & - & - & - \\
\hline
\end{tabular}

a Reaction conditions: 4-hydroxy-6-methylpyran-2-one $1.0 \mathrm{mmol}$, aromatic aldehyde $1.0 \mathrm{mmol}$, malononitrile $1.0 \mathrm{mmol}$, SBSA $4.2 \mathrm{~mol} \%$, solvent-free.

${ }^{\mathrm{b}}$ Isolated yield. 
size and increase of surface area and accelerated the motion of suspended particles to allow better mass transfer [32]. Frequencies below $50 \mathrm{kHz}$ are generally preferred for heterogeneous systems due to the more intense mechanical effects [33]. Hence, in the present method, $35 \mathrm{kHz}$ was selected for maximum sonication. The model reaction was subjected to ultrasonic irradiation initially for $2 \mathrm{~min}$ in the presence of SBSA (4.2 mol\%) at room temperature, but no product was detected (TLC monitoring). Then sonication was continued and product formation (2e) was noticed. After $10 \mathrm{~min}$, the product formation reached $95 \%$ yield. Continuation of sonication for $15 \mathrm{~min}$ did not affect the yield. It was deduced that the ultrasound irradiation accelerated the reaction. The need of just one third of the reaction time (10 min versus $60 \mathrm{~min}$ ) and the lower temperature (r.t. versus $60^{\circ} \mathrm{C}$ ) showed that ultrasonic chemical activation clearly affected the course of the reaction, increasing its energy efficiency.

In order to evaluate the generality of this model reaction, a range of 2-amino-4-aryl-7-methyl-5-oxo-4,5-dihydropyrano [4,3-b]pyran-3-carbonitriles $\mathbf{2 a - \mathbf { m }}$ were prepared under the optimized reaction conditions in the presence of SBSA (Table 1). Aryl aldehydes with electron-donating and electron-withdrawing substituents and heteryl aldehydes provided the desired dihydropyrano[4,3-b]pyrans in good to high yields without any side product (Table 1, entries 1-13). However, aliphatic aldehydes did not undergo pyranization even after a long reaction time and at an elevated temperature. TLC and GC-MS analysis of the reaction mixture showed numerous products. Electron-donating substituents caused lower yields and needed longer reaction times than electron-withdrawing substituents (Table 1, entries 5, 7, 9, and 10). 4,4'-(1,4-Phenylene) bis(2-amino-7-methyl-5-oxo-4,5-dihydropyrano[4,3-b]pyran-3 -carbonitrile $\mathbf{2 m}$ was obtained in $80 \%$ yield when terephthaldehyde $1 \mathrm{~m}$ was reacted with malononitrile and 4-hydroxy6-methylpyran-2-one in the molar ratio 1.0:2.0:2.0 under the optimized reaction conditions (Table 1 , entry 13). 4-Dimethylaminobenzaldehyde failed to give the corresponding pyran

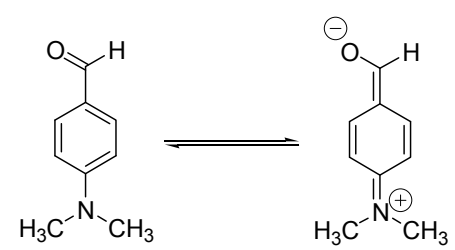

Scheme 3. Tautomerisation with formation of a quinonoid structure.

\section{Table 2}

Reusability of SBSA for the synthesis of 2-amino-4-(4-nitrophenyl)-7methyl-5-oxo-4,5-dihydropyrano[4,3-b]pyran-3-carbonitrile (2e) under optimized conditions.

\begin{tabular}{lccccc}
\hline \multirow{2}{*}{ Run } & \multicolumn{2}{c}{ Thermal condition $\left(60^{\circ} \mathrm{C}\right)$} & & \multicolumn{2}{c}{ Ultrasound irradiation } \\
\cline { 2 - 3 } \cline { 5 - 6 } & $\begin{array}{c}\text { Time } \\
(\mathrm{min})\end{array}$ & $\begin{array}{c}\text { Isolated yield } \\
(\%)\end{array}$ & & $\begin{array}{c}\text { Time } \\
(\mathrm{min})\end{array}$ & $\begin{array}{c}\text { Isolated yield } \\
(\%)\end{array}$ \\
\hline 1 & 60 & 88 & & 10 & 95 \\
2 & 60 & 88 & & 10 & 94 \\
3 & 60 & 88 & & 12 & 94 \\
4 & 60 & 86 & & 12 & 93 \\
5 & 62 & 86 & & 12 & 93 \\
\hline
\end{tabular}

derivative and the starting materials were quantitatively recovered under the same conditions (Table 1, entry 14). The explanation for this result may be that the strong electron-donating dimethylamino group reduced the reactivity. A degree of tautomerisation occurred with the formation of a quinonoid structure as shown in Scheme 3, which thus decreased the reactivity of the aldehyde group [34].

New products were characterized by IR, ${ }^{1} \mathrm{H}$ NMR, ${ }^{13} \mathrm{C}$ NMR, MS spectra, and elemental analysis, and known products were characterized by IR and ${ }^{1} \mathrm{H}$ NMR and comparison of their M.p. with those of reference samples.

SBSA was isolated and could be recycled up to five times without any significant loss of activity (Table 2).

A proposed mechanism for the formation of the product via tandem Knoevenagel-cyclo condensation is outlined in Scheme 4. The carbonyl group of the aldehyde was activated by the Brönsted acid SBSA (1). Next, nucleophilic attack of the malo-
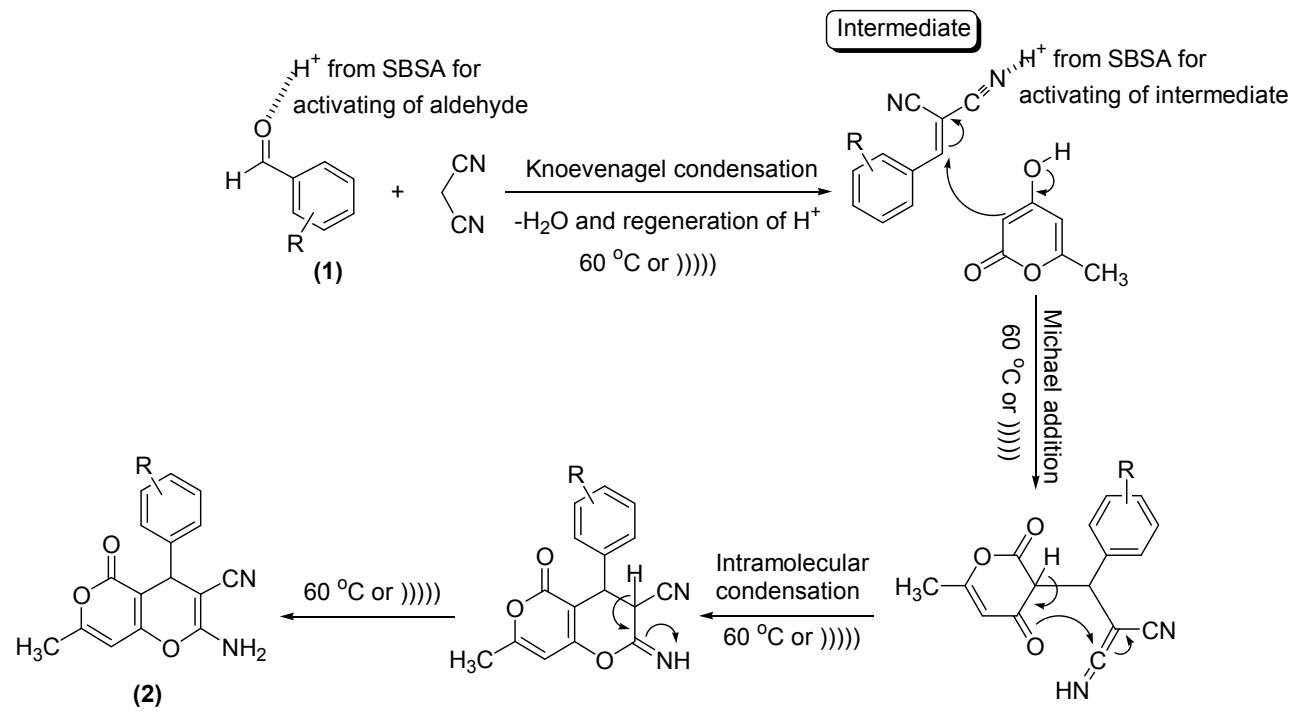

Scheme 4. Proposed mechanism for the synthesis of 2-amino-4-aryl-7-methyl-5-oxo-4,5-dihydropyrano[4,3-b]pyran-3-carbonitriles in presence of $[\mathrm{BBMIm}]\left(\mathrm{HSO}_{4}\right)_{2}$ at $60^{\circ} \mathrm{C}$. 
Table 3

Comparison of the present method with other reported strategies for the synthesis of 2-amino-4-phenyl-7-methyl-5-oxo-4,5-dihydropyrano[4,3-b]pyran-3-carbonitrile.

\begin{tabular}{|c|c|c|c|c|c|}
\hline Entry & Catalyst & Conditions & Time (min) & Yield (\%) & Ref. \\
\hline 1 & $\mathrm{NH}_{4} \mathrm{OAc}(10 \mathrm{~mol} \%)$ & Neat, r.t. & 10 & 94 & [5] \\
\hline 2 & {$[\mathrm{bmim}]\left[\mathrm{BF}_{4}\right](1.5 \mathrm{~g})$} & $80^{\circ} \mathrm{C}$ & 180 & 85 & [10] \\
\hline 3 & Piperidine (1-2 drops) & $\mathrm{MeOH}$, reflux & 60 & 79 & [37] \\
\hline 4 & $\mathrm{KF}-\mathrm{Al}_{2} \mathrm{O}_{3}$ & EtOH, r.t. & 480 & $76^{\mathrm{a}}$ & [39] \\
\hline 5 & $1,1,3,3-N, N, N, N$-Tetramethylguanidinium trifluoroacetate (TMGT) (1 mol\%) & $100^{\circ} \mathrm{C}$ & 60 & 77 & [40] \\
\hline 6 & - & $\mathrm{H}_{2} \mathrm{O}, 80^{\circ} \mathrm{C}$ & 630 & 65 & [41] \\
\hline 7 & $\mathrm{MgO}(0.25 \mathrm{~g})$ & $\mathrm{H}_{2} \mathrm{O} / \mathrm{EtOH}$, reflux & 30 & 89 & [42] \\
\hline 8 & $\mathrm{H}_{6} \mathrm{P}_{2} \mathrm{~W}_{18} \mathrm{O}_{62} \cdot 18 \mathrm{H}_{2} \mathrm{O}(1 \mathrm{~mol} \%)$ & $\mathrm{H}_{2} \mathrm{O}$, reflux & 60 & 94 & [43] \\
\hline 9 & {$[\mathrm{BBMIm}]\left(\mathrm{HSO}_{4}\right)_{2}(500 \mathrm{mg})$} & Neat, $60^{\circ} \mathrm{C}$ & 35 & 94 & [44] \\
\hline 10 & Thiourea dioxide (TUD) & $\mathrm{H}_{2} \mathrm{O}, 80^{\circ} \mathrm{C}$ & 40 & 92 & [45] \\
\hline 11 & SBSA (4.2 mol\%) & Neat, $60^{\circ} \mathrm{C}$ & 60 & 88 & this work \\
\hline 12 & $\operatorname{SBSA}(4.2 \mathrm{~mol} \%)$ & Neat ultrasound irradiation & 10 & 95 & this wor \\
\hline
\end{tabular}

nonitril on the carbonyl carbon formed the intermediate arylidene malononitrile. Subsequent Michael addition of 4-hydroxy-6-methylpyran-2-one followed by cyclization afforded the product (2).

To validate the proposed mechanism, the synthesis of $\mathbf{2} \mathbf{b}$ was carried out in two steps. First, 4-chlorobenzylidene malononitrile was prepared by the condensation of 4-chlorobenzaldehyde $\mathbf{1 b}$ and malononitrile in the presence of SBSA under thermal or ultrasonic conditions. Then the product of the first step was reacted with 4-hydroxy-6-methylpyran-2-one in the presence of SBSA to give the product $\mathbf{2 b}$ in $87 \%$ and $92 \%$ yield in 45 and $8 \mathrm{~min}$ in the presence of SBSA under thermal or ultrasonic conditions, respectively. This provided the evidence in support of the intermediate arylidene malononitrile in the proposed pathway.

The comparison of the present methodology with previously reported procedures for the synthesis of $\mathbf{2 a}$ is shown in Table 3 . As can be seen, the reaction catalyzed by SBSA at $60{ }^{\circ} \mathrm{C}$ gave a comparable yield, required less catalyst and less time than the other protocols, and also the catalyst was reusable.

\section{Conclusions}

A novel Brönsted acid was introduced and its catalytic activity was investigated for the synthesis of 2-amino-4-aryl-7-methyl-5-oxo-4,5-dihydropyrano[4,3- $b]$ pyran-3-carbonitrile de- rivatives under thermal and ultrasonic conditions. To prepare the catalyst, solar energy was applied and a hazardous material, namely, chlorosulfonic acid, was avoided. The current method has the advantages of a simple experimental procedure, use of ultrasound irradiation as an eco-environmental technology, gave good to high yield of the products, and has reusability of the catalyst.

\section{Acknowledgments}

The authors are thankful to the financial support from University Malaya to Project GC 001A-14-AET.

\section{References}

[1] De Clercq E. Farmaco, 1999, 54: 26

[2] Parreira R L T, Abrahão O, Galembeck S E. Tetrahedron, 2001, 57: 3243

[3] Presti E L, Boggia R, Feltrin A, Menozzi G, Dorigo P, Mosti L. Farmaco, 1999, 54: 465

[4] Anderson W K, Dean D C, Endo T.J Med Chem, 1990, 33: 1667

[5] Rajguru D, Keshwal B S, Jain S. Med Chem Res, 2013, 22: 5934

[6] Dragovich P S, Prins T J, Zhou R, Brown E L, Maldonado F C, Fuhrman S A, Zalman L S, Tuntland T, Lee C A, Patick A K, Matthews D A, Hendrickson T F, Kosa M B, Liu B, Batugo M R, Gleeson J P R, Sakata S K, Chen L J, Guzman M C, Meador J W III, Ferre R A, Worland S T. J Med Chem, 2002, 45: 1607

\section{Graphical Abstract}

Chin. J. Catal., 2015, 36: 728-733 doi: 10.1016/S1872-2067(14)60307-7

\section{4-(Succinimido)-1-butane sulfonic acid as a Brönsted acid catalyst for the synthesis of pyrano[4,3-b]pyran derivatives using thermal and ultrasonic irradiation}

Nader Ghaffari Khaligh *, Sharifah Bee Abd Hamid

University Malaya, Malaysia

4-(Succinimido)-1-butane sulfonic acid as an efficient and reusable Brönsted acid catalyzed the synthesis of pyrano[4,3- $b]$ pyran derivatives under ultrasound irradiation. The preparation of 4-(Succinimido)-1butane sulfonic acid is more simple and safer than of succinimide sulfonic acid.
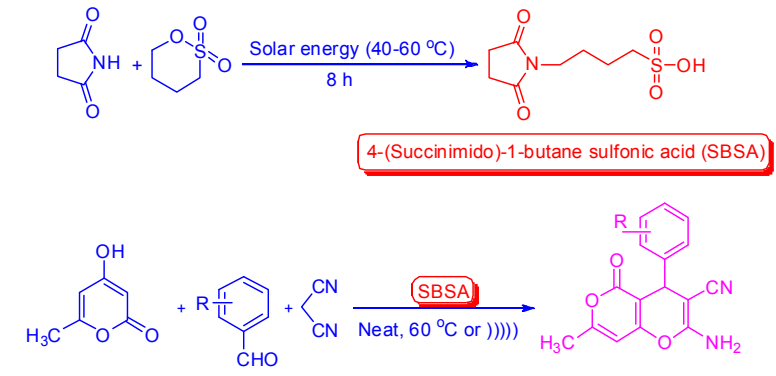
[7] Kemnitzer W, Kasibhatla S, Jiang S C, Zhang H, Zhao J H, Jia S J, Xu L F, Crogan-Grundy C, Denis R, Barriault N, Vaillancourt L, Charron S, Dodd J, Attardo G, Labrecque D, Lamothe S, Gourdeau H, Tseng B, Drewe J, Cai S X. Bioorg Med Chem Lett, 2005, 15: 4745

[8] Kemnitzer W, Drewe J, Jiang S C, Zhang H, Wang Y, Zhao J H, Jia S J, Herich J, Labreque D, Storer R, Meerovitch K, Bouffard D, Rej R, Denis R, Blais C, Lamothe S, Attardo G, Gourdeau H, Tseng B, Kasibhatla S, Cai S X. J Med Chem, 2004, 47: 6299

[9] Kemnitzer W, Drewe J, Jiang S C, Zhang H, Zhao J H, Crogan-Grundy C, Xu L F, Lamothe S, Gourdeau H, Denis R, Tseng B, Kasibhatla S, Cai S X. J Med Chem, 2007, 50: 2858

[10] Fan X S, Feng D, Qu Y Y, Zhang X Y, Wang J J, Loiseau P M, Andrei G, Snoeck R, Clercq E D. Bioorg Med Chem Lett, 2010, 20: 809

[11] Tatsuta K, Yamaguchi T, Tsuda Y, Yamaguchi Y, Hattori N, Nagai H, Hosokawa S. Tetrahedron Lett, 2007, 48: 4187

[12] Tanabe K, Hölderich W F. Appl Catal A, 1999, 181: 399

[13] Cole-Hamilton D J. Science, 2003, 299: 1702

[14] Chakrabarti A, Sharma M M. React Polym, 1993, 20:1

[15] Riego J M, Sedin Z, Zaldivar J M, Marziano N C, Tortato C. Tetrahedron Lett, 1996, 37: 513

[16] Turro N J. Tetrahedron, 1987, 43: 1589

[17] Zolfigol M A, Chehardoli G, Dehghanian M, Niknam K, Shirini F, Khoramabadi-Zad A.J Chin Chem Soc, 2008, 55: 885

[18] Weber U S, Steffen B, Siegers C P. Res Commun Mol Pathol Pharmacol, 1998, 99: 193

[19] Du B X, Yin M Y, Zhang M M, Li Y L, Wang X S. J Heterocycl Chem, 2012, 49: 1439

[20] Patil A D, Freyer A J, Eggleston D S, Haltiwanger R C, Bean M F, Taylor P B, Caranfa M J, Breen A L, Bartus H R, Johnson R K, Hertzberg R P, Westley J W. J Med Chem, 1993, 36: 4131

[21] Anastas P T, Warner J C. Green Chemistry: Theory and Practice. Oxford: Oxford Univ Press, 1998

[22] Mason T J. Ultrason Sonochem, 2007, 14: 476

[23] Khaligh N G, Shirini F. Ultrason Sonochem, 2013, 20: 26
[24] Khaligh N G. Ultrason Sonochem, 2013, 20: 1062

[25] Cravotto G, Cintas P. Chem Soc Rev, 2006, 35: 180

[26] Xia M, Lu Y D. Ultrason Sonochem, 2007, 14: 235

[27] Shirini F, Khaligh N G. Phosphorus Sulfur Silicon Relat Elem, 2011, 186: 2156

[28] Shirini F, Khaligh N G. Dyes Pigm, 2012, 95: 789

[29] Shirini F, Khaligh N G. Chin J Catal (催化学报), 2013, 34: 695

[30] Shirini F, Khaligh N G. Chin J Catal (催化学报), 2013, 34: 1890

[31] Suslick K S, Didenko Y, Fang M M, Hyeon T, Kolbeck K J, McNamara W B III, Mdleleni M M, Wong M. Philos Trans R Soc A, 1999, 357: 335

[32] Mason T J, Peters D. Practical Sonochemistry: Power Ultrasound Uses and Applications. 2nd Ed. Chichester: Horwood Publishing, 2002. 17

[33] Luche J L. Synthetic Organic Sonochemistry. New York: Plenum Press, 1998

[34] Jin T S, Sun G, Li Y W, Li T S. Green Chem, 2002, 4: 255

[35] Piao M Z, Imafuku K. Tetrahedron Lett, 1997, 38: 5301

[36] Magedov I V, Manpadi M, Ogasawara M A, Dhawan A S, Rogelj S, Van Slambrouck S, Steelant W F A, Evdokimov N M, Uglinskii P Y, Elias E M, Knee E J, Tongwa P, Antipin M Y, Kornienko A. J Med Chem, 2008, 51: 2561

[37] Stoyanov E V, Ivanov I C, Heber D. Molecules, 2000, 5: 19

[38] Shi D Q, Niu L H, Zhuang Q Y. Chin J Org Chem (史达清, 牛力惠, 庄 启亚. 有机化学), 2008, 28: 1633

[39] Wang X S, Zeng Z S, Li Y L, Shi D Q, Tu S J, Zhou J X. Arkivoc, 2006, (11): 107

[40] Shaabani A, Samadi S, Badri Z, Rahmati A. Catal Lett, 2005, 104: 39

[41] Shaabani A, Samadi S, Rahmati A. Synth Commun, 2007, 37: 491

[42] Seifi M, Sheibani H. Catal Lett, 2008, 126: 275

[43] Rajguru D, Keshwal B S, Jain S. Chin Chem Lett, 2013, 24: 1033

[44] Khaligh N G. Monatsh Chem, 2014, 145: 1643

[45] Ghashang M, Mansoor S S, Aswin K. Chin J Catal (催化学报), 2014, 35: 127 